\title{
THE EFFECT OF NITROGEN FERTILISATION AND CERTAIN OTHER FACTORS ON THE CHEMICAL COMPOSITION OF APPLE LEAF ${ }^{\mathrm{l}}$ )
}

\author{
J. VAN DER BOON and A. POUWER \\ Institute for Soil Fertility, Groningen, and \\ Horticultural Advisory Service, Kesteren, Netherlands
}

\begin{abstract}
Summary
Increasing dressings of nitrolime applied to apple trees lead to an increase in the $\mathrm{N}$ and $\mathrm{Mg}$ contents of the leaf and a fall in the $\mathrm{K}, \mathrm{P}$ and $\mathrm{Ca}$ contents. $\mathrm{Ca}$ is the only element whose behaviour does not coincide with what is stated in the literature.

In the discussion of the results it is pointed out that the time and place of sampling may result in a different pattern. The chemical form of the nitrogen in the fertilizer is also important.

Various factors are adduced in explanation of the divergent behaviour of the nutrient elements, viz. growth dilution, antagonisms in uptake, altered distribution between plant parts and increase in the exchange capacity of the root surface caused by nitrogen.

The mineral content of the leaf shows greater variations over a sequence of years as the alteration, effected by fertilizer treatment. Yield and weather has an influence too.

As regards advice on fertilisation, it follows from the investigation that it is important to adjust the phosphate and potash dressings to the nitrogen dressing.
\end{abstract}

\section{INTRODUCTION}

A five-year study was made of the effect of increasing dressings of nitrolime on the chemical composition of the leaf of Jonathan appletree grown on M IV. This effect is a cumulative one since the varying amounts of nitrolime were applied to the same plots every year. The amounts of nutrient elements found in the leaf analysis are shown as percentages by weight of the dry matter, so that an insight is also obtained into the concentration thereof in the leaf. The total amounts of nutrient elements taken up by the tree as a result of the various dressings were not determined.

Consideration was given to the divergent behaviour in the leaf of the relative contents of $\mathrm{N}$ and $\mathrm{Mg}$ compared to the $\mathrm{K}, \mathrm{Ca}$ and $\mathrm{P}$ contents. There was also a discussion of the importance to be attached to this in connection with practical advice on fertilisation.

\section{EXPERIMENTAL ARRANGEMENT}

An orchard with 10 years old Jonathan apples on M IV was divided into plots receiving either $100,170,240$ and $310 \mathrm{~kg} \mathrm{~N} / \mathrm{ha}$. These dressings are respectively to be regarded as moderate, normal to optimum and extreme. The nitrogen was applied in the early part of the year in the form of nitrolime. Each plot contained three experimental trees. The experiment consisted of 20 replications.

At the beginning of the experiment in 1954 the soil was tested according to the methods of the Soil Testing Laboratory at Oosterbeek, with the following results :

1) Received for publication, June 4, 1960. 


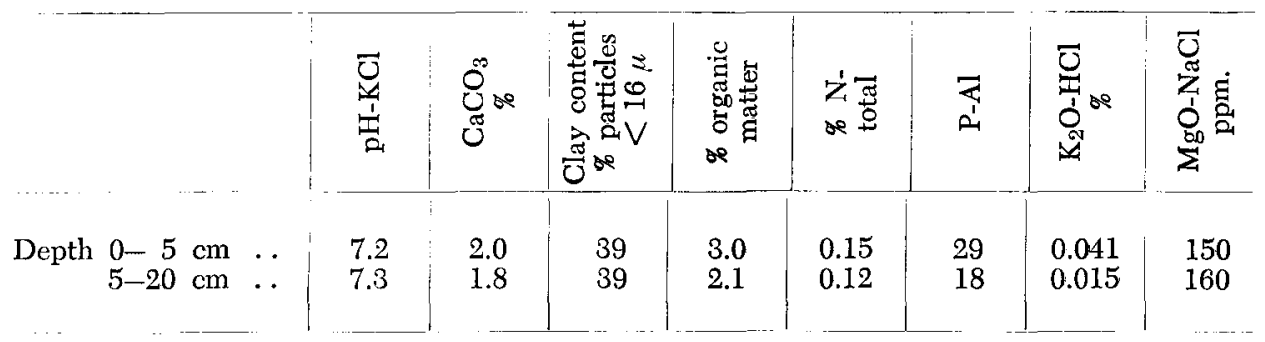

N.B. $0.002 \%$ of in water soluble $\mathrm{N}$ was found in the $0-20 \mathrm{~cm}$ layer.

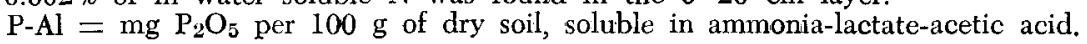

The soil is a medium-heavy river ridge soil containing a small amount of calcium carbonate and a moderate percentage of organic matter. The total nitrogen content is fairly low, as is also the amount of water-soluble nitrogen, according to the determination at a specific moment. The $\mathrm{P}-\mathrm{Al}$ number and the magnesia number are almost adequate, but the potash content is on the low side.

The potash and phosphate dressings were kept equal throughout the orchard. $80 \mathrm{~kg}$ of $\mathrm{P}_{2} \mathrm{O}_{\overline{5}}$ and $200 \mathrm{~kg}$ of $\mathrm{K}_{2} \mathrm{O}$ were applied per annum in the form of superphosphate and sulphate of potash respectively.

In 1954 the soil was cultivation, but in the experimental period the orchard had a grass cover.

At the end of July or the beginning of August the 3th and the 4th leaf from the basis of the shoots were collected of 5 replications and analysed by the Oosterbeek Laboratory. The apple yield in each plot was visually estimated pre-harvest. In 1955 the yield was very moderate, and owing to severe night frost no crop was obtained in 1957.

\section{RESULTS}

During the first year of the experiment the nitrogen rates had not much effect on the growth and appearance of the trees. During the following years there was a considerable difference between the lowest and highest nitrogen dressing $(0 \mathrm{~N}$ and $3 \mathrm{~N}$ respectively) as regards the number of leaves and shoots. Trees which had been given the highest nitrogen dressing had considerably more foliage and shoots than those with the lowest dressing. No marked differences in growth between the $1 \mathrm{~N}, 2 \mathrm{~N}$ and $3 \mathrm{~N}$ treatments were observed, except to a slight extent between the $1 \mathrm{~N}$ and $3 \mathrm{~N}$ stages during the first experimental years.

As regards the effect of nitrolime on the chemical composition of the leaf and the yield, tabel 1 a shows the effect of the nitrogen dressing as an average of the five experimental years 1954-1958, and table $1 \mathrm{~b}$ shows whether the effect found is to be regarded as statistically significant.

The $\mathrm{N}$ content of the leaf was subject to a marked rise from $2.19 \%$ at $100 \mathrm{~kg}$ $\mathrm{N} / \mathrm{ha}$ to $2.38 \%$ at $310 \mathrm{~kg} \mathrm{~N} / \mathrm{ha}$. This fertiliser effect was found to be very significant (table $1 \mathrm{~b}:+++$ ) between the lower and higher amounts, the difference in effect was found to be mainly due to the contrast between the lowest dressing and the higher dressings together (100 kg compared to 170 to $310 \mathrm{~kg}$; $\left.\mathrm{N}_{0}: \mathrm{N}_{1}, 2_{3}\right)$. This is also the case with the other significant effect such as that of nitrogen on the $\mathrm{P}_{2} \mathrm{O}_{5} \%$ and on the sum of the cations (CS). This means that the lines representing the relationship between the content and the $\mathrm{N}$ dressing are curvillinear, i.e. after a steep initial rise or fall the higher dressings only 
Table 1a Effect of nitrolime on nutrient elements (1954 to 1958) and on sugar content in the leaf and crop (three experimental years).

\begin{tabular}{|c|c|c|c|c|c|c|c|c|c|c|c|}
\hline $\mathrm{N}$ & age & $\mathrm{N} \%$ & $\underset{\%}{\mathrm{P}_{2} \mathrm{O}_{5}}$ & $\underset{\%}{\mathrm{~K}_{2} \mathrm{O}}$ & $\underset{\%}{\mathrm{CaO}}$ & $\underset{\%}{\mathrm{MgO}}$ & \multirow[t]{2}{*}{$\begin{array}{l}\mathrm{K}_{2} \mathrm{O} / \\
\mathrm{MgO}\end{array}$} & $\begin{array}{l}\left.\mathrm{CS}^{1}\right) \\
\mathrm{g} \text { equ }\end{array}$ & $\begin{array}{l}\text { CS } \\
\left.\text { AS }{ }^{1}\right) \\
\mathrm{g} \text { at. }\end{array}$ & \multirow{2}{*}{ 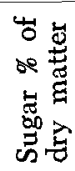 } & \multirow{2}{*}{ 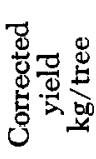 } \\
\hline ha & c & \multicolumn{5}{|c|}{ of dry matter } & & \multicolumn{2}{|c|}{ per $100 \mathrm{~g}$} & & \\
\hline 100 & 0 & 2.1 & 0. & & 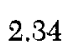 & 035 & 4.23 & & 0.82 & 6.68 & 21.6 \\
\hline 170 & 1 & 2 & & & & & 3.5 & & & & 21.9 \\
\hline 240 & 2 & 2. & 0. & 1. & 2.8 & 0. & 3.30 & 0 . & 5 & 6. & 22.2 \\
\hline 310 & 3 & 2.38 & 0.4 & 1.2 & 2.15 & 0.38 & 3.37 & 0.123 & 0.70 & 6.75 & 21.0 \\
\hline
\end{tabular}

1) $\mathrm{CS}=$ Cation Sum $(\mathrm{K}+\mathrm{Ca}+\mathrm{Mg})$.

AS $=$ Anion Sum $(N+P)$.

Table $1 \mathrm{~b}$ Effect of nitrolime and interaction of nitrogen and year, statistically tested.

\begin{tabular}{|c|c|c|c|c|c|c|c|c|c|c|}
\hline & N \% & $\underset{\%}{\mathrm{P}_{2} \mathrm{O}_{5}}$ & $\underset{\%}{\mathrm{~K}_{2} \mathrm{O}}$ & $\underset{\%}{\mathrm{CaO}}$ & $\underset{\%}{\mathrm{MgO}}$ & $\begin{array}{l}\mathrm{K}_{2} \mathrm{O} / \\
\mathrm{MgO}\end{array}$ & $\begin{array}{c}\text { CS } \\
\text { g equ. }\end{array}$ & $\begin{array}{c}\text { CS/AS } \\
\mathrm{g} \text { at. }\end{array}$ & $\underset{\mathbb{6}}{\text { Sugar }}$ & $\begin{array}{c}\text { Corrected } \\
\text { yield } \\
\mathrm{kg} / \text { tree }\end{array}$ \\
\hline $\begin{array}{l}\mathrm{N} \text { effect } \ldots \\
\text { Contrast } \\
\mathrm{N}_{0}: \mathrm{N}_{1,2,3} \\
\text { Interaction } \\
\text { years } \times N \text {. }\end{array}$ & $\begin{array}{r}++ \\
++ \\
+\end{array}$ & $\begin{array}{r}++ \\
++ \\
+++\end{array}$ & $\begin{array}{l}0 \\
0 \\
0\end{array}$ & $\begin{array}{l}0 \\
0 \\
0\end{array}$ & $\begin{array}{c}+ \\
0 \\
(+)\end{array}$ & $\begin{array}{l}0 \\
0 \\
+\end{array}$ & $\begin{array}{l}+ \\
+ \\
0\end{array}$ & $\begin{array}{c}+++ \\
+++ \\
+\end{array}$ & $\begin{array}{l}0 \\
0 \\
0\end{array}$ & $\begin{array}{l}0 \\
0 \\
0\end{array}$ \\
\hline
\end{tabular}

$0=$ statistically nonsignificant.

$+=$ statistically signifioant, probability level $P=0.05$.

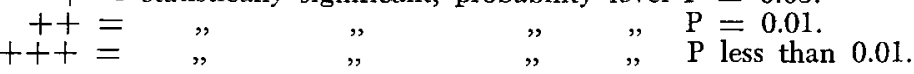

have a slight effect. There is only a more uniform rise in the case of the $\mathrm{Mg}$ content (fig. 1).

Increasing the $100 \mathrm{~kg}$ dressing by $70 \mathrm{~kg} \mathrm{~N} / \mathrm{ha}$ only results into a rise of
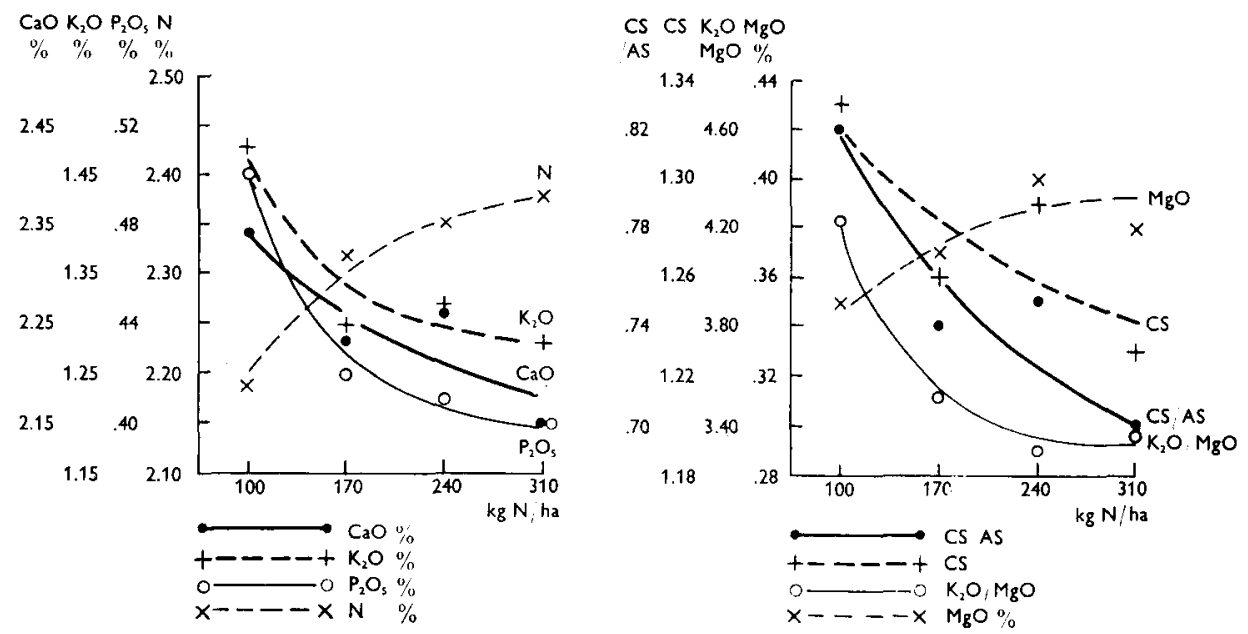

Fig. 1 The efFect of Nitrolime on the Chemical composition of apple leaf. ${ }^{1}$ )

1) The figures $1.34,1.30,1.26,1.22$ and 1.18 (column CS) should be read as 0.134, $0.130,0.126,0.122$ and 0.118 . 
$2.32-2.19=0.13 \%$ in the $\mathrm{N}$ content of the leaf, viz. an increase of only $6 \%$ of the original content. The slight effect of fertilisers on the chemical composition of the leaf was also noticeable in other feriliser experiments (42).

The relative phosphate content in the leaf falls considerably as a result of the nitrogen dressing mainly in fact owing to the first higher fertilisation rate. Although the potassium content is also subject to a decrease, this change, unlike that occurring in the phosphate content, is nonsignificant. The significant increase in the $\mathrm{Mg}$ content caused by nitrogen, with the simultaneous fall in the potassium content, means, of course, that the $\mathrm{K} / \mathrm{Mg}$ ratio in the leaf falls as well. The effect of the nitrolime dressing on the calcium content is slight. The small decrease is nonsignificant. The dressing causes a drop in the sum of the $\mathbf{K}+$ $\mathrm{Ca}+\mathrm{Mg}$ cations, expressed in gram equivalents per $100 \mathrm{~g}$, as well as in the ratio of the cation to the $\mathrm{N}+\mathrm{P}$ anion sums, expressed as gram atoms per 100 grams.

The dressing did not cause any significant change in the sugar content which was only determined in 1954, 1955 and 1957. The average corrected yield over the five years of the experiment increases as far as the $240 \mathrm{~kg} \mathrm{~N} /$ ha dressing, after which it is again lower at the highest $\mathbf{N}$ stage. But these differences are statistically nonsignificant. The fact that the yield rises with the dressing agrees with practical experience. That the yield should only show a slight rise, is in agreement with the results of the soil nitrogen investigation and the interpretation obtained (4):

Table 2 Soil investigation for water-soluble nitrogen.

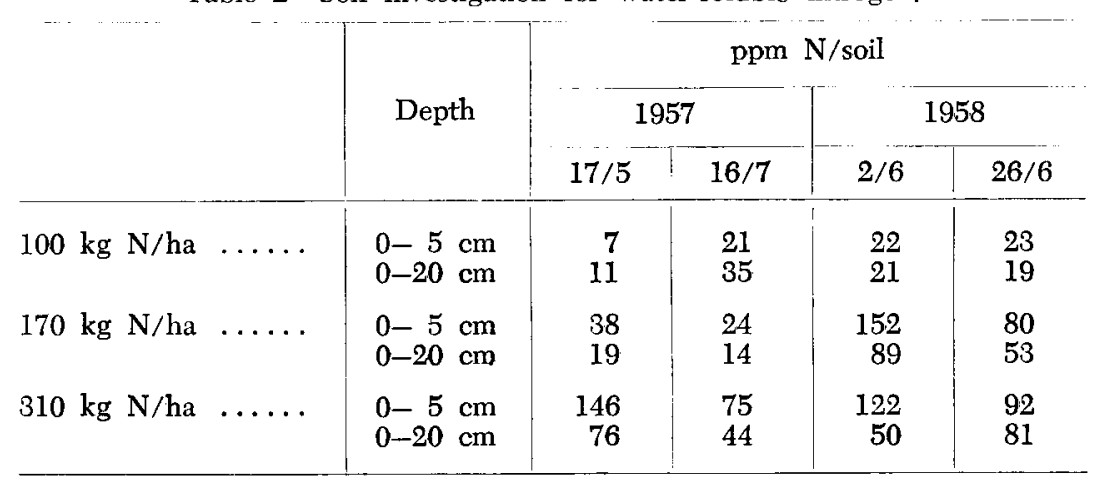

It was, in fact, concluded from the trial site survey of Jonathans in the Betuwe district of Holland that the content of a soil sample taken in June from the $0-20 \mathrm{~cm}$ layer should be at least $25 \mathrm{ppm} \mathrm{NO}_{3}-\mathrm{N}$ to be sure of a good growth and fruit setting. Above this content there is only a slight improvement in the vigour of the tree. The yields were corrected for differences in the size of the tree measured before the experiment. The product of the height and the breadth, measured in two directions at right-angles to each other, was taken as the index of the tree volume (9). It should be noted however that since the trees were planted too near each other the increased growth resulting from the various nitrogen dressings could not be converted into production as most of this growth was removed again by pruning. For this reason no definite statement can be made here concerning the return of the various nitrogen dressings. 
In this trial field it was not noticed that the various nitrogen stages had any effect on the colour of the fruit.

As regards the relationships between the nutrient elements in the leaf, it is clear that the $\mathrm{N} / \mathrm{P}, \mathrm{N} / \mathrm{K}$ and $\mathrm{N} / \mathrm{Ca}$ ratios increase with the dressings. There is no distinct change in the $\mathrm{N} / \mathrm{Mg}$ ratio as a result of the dressing (table 3).

Table 3 Effect of nitrolime on the ratios of leaf elements (1954 to 1958).

\begin{tabular}{|c|c|c|c|c|c|c|c|c|}
\hline \multicolumn{2}{|c|}{ N stage } & \multirow{2}{*}{$\mathrm{N} / \mathrm{Mg}$} & \multirow{2}{*}{$\mathrm{K} / \mathrm{P}$} & \multirow{2}{*}{$\mathrm{Ca} / \mathrm{P}$} & \multirow{2}{*}{$\mathrm{Mg} / \mathrm{P}$} & \multirow{2}{*}{$\begin{array}{l}\mathrm{K} / \mathrm{Ca} \\
\times 10\end{array}$} & \multirow{2}{*}{$\mathrm{K} / \mathrm{Mg}$} & \multirow{2}{*}{$\mathrm{Ca} / \mathrm{Mg}$} \\
\hline $\mathrm{kg} \mathrm{N} / \mathrm{ha}$ & Code & & & & & & & \\
\hline $\begin{array}{l}100 \\
170 \\
240 \\
310\end{array}$ & $\begin{array}{l}0 \\
1 \\
2 \\
3\end{array}$ & $\begin{array}{l}8.97 \\
8.96 \\
8.00 \\
9.00\end{array}$ & $\begin{array}{l}4.44 \\
4.64 \\
4.82 \\
4.83\end{array}$ & $\begin{array}{l}11.9 \\
13.7 \\
14.0 \\
13.8\end{array}$ & $\begin{array}{l}2.48 \\
3.16 \\
3.49 \\
3.39\end{array}$ & $\begin{array}{l}3.89 \\
3.57 \\
3.58 \\
3.69\end{array}$ & $\begin{array}{l}1.86 \\
1.53 \\
1.41 \\
1.47\end{array}$ & $\begin{array}{l}4.82 \\
4.33 \\
4.00 \\
4.04\end{array}$ \\
\hline
\end{tabular}

Cations expressed in $\mathrm{g}$ equ. per $100 \mathrm{~g}$.

Anions " " g at. " " "

The rising $\mathrm{K} / \mathrm{P}, \mathrm{Ca} / \mathrm{P}$ and $\mathrm{Mg} / \mathrm{P}$ ratios show that the phosphate content undergoes a comparatively steeper drop.

With an increasing $\mathrm{N}$ dressing the $\mathrm{K} / \mathrm{Mg}$ ratio falls more distinctly than the $\mathrm{K} / \mathrm{Ca}$ ratio. The $\mathrm{Ca} / \mathrm{Mg}$ quotient also falls with an increasing $\mathrm{N}$ dressing.

The chemical composition of the leaf exhibits considerable differences in the years dealt with (36). These differences may exceed those obtained by fertilisation. Thus the average $\mathrm{N}$ content varied from 2.10 to $2.73 \%$, whereas fertilisation did not increase the content by more than $0.19 \%$. No tendency can be found over the various years except for a contineous rise in the potassium content of the leaf and a fall in the calcium and magnesium contents. This is probably due to the regular potassium dressing applied to the trial field, with a regular increase in the potash level of the soil.

In one year the nitrogen dressing had a more pronounced effect on the chemical composition of the leaf than in another (22). Significantly interactions occured in the $\mathrm{N}, \mathrm{P}$ and $\mathrm{Mg}$ contents and in the $\mathrm{K} / \mathrm{Mg}$ and CS/AS ratios, but there was no reversal of the reaction in the opposite direction, viz. a rise instead of a fall or vice versa.

\section{Discussion}

As regards the behaviour of the $\mathrm{N}, \mathrm{P}, \mathrm{K}$ and $\mathrm{Mg}$ contents, the results obtained are in agreement with most references in literature.

The $\mathbf{N}$ dressing leads to an increase in the $\mathbf{N}$ content and the $\mathrm{Mg}$ content $(1,6$, $7,10,11,12,13,16,22,25,35,46,49$ and 50$)$. On the other hand, there is a fall in the phosphate $(1,6,10,11,12,13,22,24,37,42,49$ and 50) and potassium contents $(3,5,6,7,10,11,12,13,14,15,16,22,25,29,35,37,49,50$ and 51$)$. There are only a few literature references in which the opposite effect is found ; for the said nutritive elements together it is found in 11,14, 16, 29, 40 and 42 .

Generally speaking, however, the literature reports a higher $\mathrm{Ca}$ content due to nitrogen fertilisation $(1,6,11,12,49$ and 50$)$. There is also some drop in the sugar content $(2,6)$, an effect not found in the present experiment.

It should not be thought, however, that shifts are always reflected equally 
clearly, except of course in the case of the nitrogen content, although when the contents are high, there will only be a slight rise (8). The size of the change probably depends on the amount in the soil accessible to the plant. This is probably the reason why one investigator found a more distinct drop in phosphate and the other in potassium. Thus the fall in the potassium content decreased with increasing application of potash to the plant $(40,59)$. But this was not found by CAIN (10).

These shifts in the leaf contents are only to be expected under normal practical conditions. With very low contents of the element in question other changes occur $(13,40)$. Thus in a trial field on which the trees were suffereing from severe potash deficiency is was found that the potash shortage fell when nitrogen was applied (possibly owing to improved root growth) and that after a substantial increase in the potash level of the soil the visual symptoms of $\mathrm{K}$ deficiency were actually increased by nitrogen. This is the possible explanation of the fact that at the central fertilization trial field "De Lange Ossekampen", Wageningen, the apples and pears were not subject to such severe potash deficiency by $\mathrm{N}$ dressing (42). The content of other ions may also influence the behaviour of the element studied $(19,25,40)$. Thus when nitrolime was applied to rye-grass, there was a greater increase in the calcium content with decreasing potassium and sodium contents in the leaf (17).

Making use of the literature references, we took the opportunity to consider which mechanisms may have led to the differences between the contents caused by the nitrogen dressing. It is obviously impossible to discover the right explanation by means of the experiment described here.

In general growth is greatly promoted by nitrogen. When a nitrogen dressing is applied and the supply of the other ions is kept constant, it is clear that these elements will fall in proportion owing to "growth dilution" (17). There will usually be an increase in the content of the element supplied, although over the very low range of the fertilisation treatment there may also be a relative fall in this element as a result of a great increase in growth $(43,44)$. A fall in the phosphate and potassium contents could therefore be explained by this theory. The steep fall in contents caused by the $1 \mathrm{~N}$ stage and the slight effect of the higher stages are in agreement with the observed differences in growth. But the behaviour of magnesium shows that growth dilution is not the only phenomenon. Moreover CaIN has demonstrated that when the nitrogen dressing is increased, less $\mathrm{P}$ and $\mathrm{K}$ and more $\mathrm{Ca}$ and $\mathrm{Mg}$ are also supplied to the leaf in absolute amounts (10).

The fact that on this trial field there was only a slight drop in the calcium content of the leaf despite the better opportunity for absorption (see below), might also be attributed to the growth dilution. Owing to the high $\mathrm{pH}$ of the soil the calcium carbonate of the nitrolime remains in insoluble form, so that no higher $\mathrm{Ca}$ ion concentration is available to the plant.

When the plant takes up the nutrient in the form of ions there must be an electrostatic balance between the amount of positive cations and negative anions taken up (38). It has frequently been found that with a change in the cation dressing, the amount and type of anions remaining the same, the absorbed cations changed but not the sum of the basic cations $(17,38,40)$. On the other hand, dressing with nitrogen in the form of ammonium nitrate causes a rise in 
both the anion and cation sums, the former rise being greater than the latter, so that the cation sum/anion sum ratio falls with increasing nitrate fertilisation $(17,38,39)$. That the cation/anion ratio may fall despite the specified electrostatic balance, is due to the fact that the nitrate in the plant is reduced, releasing an $\mathrm{OH}$ ion which can be exchanged for nitrate in the nutrient solution. There is a fall in this ratio so long as $\mathrm{N}$ is taken op and assimilated (18). The varying uptake or release of $\mathrm{HCO}_{3}$ ions may also have a regulating effect when the cation/anion ratio is disturbed by a one-sided dressing with nitrate or ammonium. The adsorption of more nitrate is accompanied by a reduction in the uptake of other anions $(17,34)$. In the present experiment there was a fall in the CS/AS quotient, but no increase in the cation sum caused by a larger nitrogen dressing, an effect which is, moreover, of fairly general occurrence. Certain important ions such as sulphate were not included in this calculation.

A possible explanation of the divergent behaviour of potassium and magnesium may also be found in the frequently observed fact that increasing nitrogen fertilisation leads to an increase in the cation adsorption capacity of the root wall $(21,28,41,48)$. This means that if the theory of the Donnan equilibrium between root and soil colloid is correct, bivalent ions are more readily adsorbed than monovalent ions. In fact, the potassium and magnesium ratios in the leaf between the lowest and the highest $\mathrm{N}$ stages do satisfy the formules given (41), viz. :

$$
\left[\begin{array}{l}
{\left[\mathrm{Mg}_{3}\right]} \\
{\left[\overline{\mathrm{M}} \mathrm{g}_{0}\right]}
\end{array}\right]^{2}=\left[\begin{array}{l}
\mathrm{K}_{0} \\
\mathrm{~K}_{3}
\end{array}\right]=\left[\begin{array}{c}
0.38 \\
-0.35
\end{array}\right]^{2}=\frac{0.148}{0.128}=1.16
$$

but the calcium does not follow this line. Thus an increasing need of potassium caused by more vigorous growth is accompanied by a reduced ability to absorb this element (28).

The changes in leaf contents due to the nitrogen dressing need to be accompanied by the same change in other parts of the plant. This is found to be particularly true of trace elements in a comparison between leaf and root (40). Growth is promoted by nitrogen. Other ions are also taken up in greater amounts during the process. A relative accumulation or reduction may occur as a result of the growth dilution and change in distribution over the various parts of the plant. Nitrogen in particular may lead to a radical change in the distribution within the plant. Thus CAIN (11) found that the higher nitrogen dressing caused a fall in the phosphate content in the foliage, but that it rose in the bark and wood of new shoots. The total amount of phosphate in the plant had increased. This was also true of the amount of potassium, but there was a reduced amount of calcium. The $\mathrm{Mg}$ level rose in both shoot and leaf. According to Bos (5) a yield increased by nitrogen may also further the shift of potash to the fruit at the expense of the leaf. It is known that in a year in which there is a good crop of fruit the leaf contains more $\mathrm{N}, \mathrm{Ca}$ and $\mathrm{Mg}$ and less $\mathrm{K}$, which is the same shift as that caused by a larger nitrogen dressing $(6,12,27,50,51)$.

If growth dilution and change in distribution over the parts of the plant are the cause, the place and time of sampling will show a different pattern. Thus CaIN and Boynton (12) found that the calcium and magnesium contents and the related CS were reduced by a larger nitrogen dressing at the beginning of the season, which is the period of rapid growth, but that later on in the season 
the position was reversed. Goodall and GREGORY concluded from their experiments that a steeper fall in the relative concentration of an element caused by application of other nutrients was found with advancing age of the plant (19).

The form in which the nitrogen was applied to the trees was not the subject of investigation. There is, however, a considerable difference in reaction of the plant according to whether the nitrogen is applied in the form of nitrate or ammonia. The $\mathrm{NH}_{4}$ ion has an antagonistic effect on the cation uptake $(30,34$, 48 ) and increases the phosphate uptake $(31,38)$. In a comparative study between $\mathrm{NH}_{4}$ and $\mathrm{NO}_{3}$ fertilisation of lemon seedlings it was found that the plant fed with nitrogen in ammonium form contained more nitrogen, while the $\mathrm{K}, \mathrm{Ca}$ and $\mathrm{Mg}$ contents were lower (48). The favourable effect of nitrate on the magnesium uptake is only found when the root encounters nitrate and magnesium together. This makes it seem likely that the physiologically acid effect of ammonium sulphate has a retarding influence (30). But there are indications that the adsorptive capacity of the root decreases owing to ammonia, with the result that calcium and magnesium are less readily absorbed $(23,48)$.

As regards the effect on the magnesium uptake, nitrolime is situated between the ammonium and nitrate form in the case of cereals, but in the case of potatoes it has the effect of nitrate, probably because ammonia is wholly converted into nitrate during the greater interval between the time of fertilising and growth in this plant (30).

By WALLACE (47) a study was made of the effect of urea on the cation and anion uptake. As regards phosphate the effect of urea depended on the crop. In respect of the cations urea had a more or less ammonia effect. When the crop was sprayed with urea there was sometimes no increase in the $\mathrm{N}$ content in the leaf (8), whereas WeEks found that unlike the effect of fertilisation, the contents of the other ions in the leaf was unchanged after spraying (49).

Mulching with the straw of non-papilionaceous plants had much in common with fertiliser nitrogen in its effect on growth, yield, late fall and fruit colour of the apple (7). The nitrogen content of the leaf rose in a similar way, but unlike the effect of fertiliser nitrogen mulching increased the potassium content of the leaf (49), while in one year of the experiment mulching led to a marked fall in the magnesium content (7). Potassium is introduced into the orchard by the mulch, which explains the difference in reaction.

Bos still found a fall in potassium content with a larger dressing of the mixed fertiliser $12+10+18$, this being attributed to the more vigorous growth which exceeds the increased supply of potash (5).

It follows from the above that the effect of nitrogen on the chemical composition of the leaf is also determined by the form of nitrogen, the crop and the time of application (possibly also by the nitrification rate). If only ammonia is applied, then ignoring nitrification and anion effect, we may expect a still greater fall in the potash content and a lesser one in the phosphate content. It will then also be possible to observe a fall in the relative $\mathrm{Ca}$ and $\mathrm{Mg}$ contents.

The leaf contents show differences from year to year. We have already pointed out the rise in the $\mathrm{K}$ content over the years and the fall in the $\mathrm{Ca}$ and $\mathrm{Mg}$ contents which were attributed to the increased potash dressing in the experimental years. As regards the remaining differences we are, of course, 
faced with the effect of weather conditions on the uptake of nutrients. As a direct cause of this we can adduce the washing out of nitrogen during winter, resulting into a lower nitrogen content in the leaf $(8)$, or a poorer yield as in the case of rye (33). A dry spring reduces the potassium uptake $(32,36)$. Owing to the small number of experimental years this is impossible to prove, although there is an indication of a lower nitrogen content in the leaf after a rainy winter.

Table 4 Increasing amount of precipitation in winter and $\mathrm{N}$ content of leaf in the succeeding summer.

\begin{tabular}{l|c|c} 
Year & $\begin{array}{c}\text { Rain in } \mathrm{mm} \\
\text { Nov. to Feb. }\end{array}$ & $\begin{array}{c}\text { N \% in leaf } \\
\text { in summer }\end{array}$ \\
\hline & & \\
1954 & 160 & 2.41 \\
1958 & 189 & 2.73 \\
1956 & 212 & 2.16 \\
1957 & 248 & 2.10 \\
1955 & 250 & 2.15 \\
\hline
\end{tabular}

The high nitrogen content in the leaf in 1958 may also be due to the regular distribution of the rainfall during the summer months which promotes the mineralisation process and the nitrogen uptake.

Indirectly a heavy fruit crop after favourable weather conditions during flowering may cause a change in the leaf contents. According to the literature $(6,12,27,50,51)$ the $\mathrm{N}, \mathrm{Ca}$ and $\mathrm{Mg}$ contents in the leaf are higher with a good crop, and the potassium content is lower. Regarding the behaviour of the phosphate the literature is contradictory. The leaf analysis figures of this experimental field, after correcting for the trend in the $\mathrm{K}, \mathrm{Ca}$ and $\mathrm{Mg}$ contents, are higher for $\mathrm{N}$ and $\mathrm{P}$ and lower for $\mathrm{K}$ during favourable years (table 5 ).

Table 5 Size of crop with the corresponding leaf analysis figures.

\begin{tabular}{l|c|c|c} 
& $\mathrm{N}$ content & P content & $\begin{array}{c}\text { K content } \\
\text { corrected }\end{array}$ \\
\hline Good harvest $1954,1956 \ldots \ldots \ldots$ & & \\
Middling or no harvest $1955,1957 \ldots$ & 2.59 & 0.43 & 1.28 \\
\end{tabular}

However, the $\mathrm{Ca}$ and $\mathrm{Mg}$ contents (not shown here) do not vary with the size of the fruit crop. The 1958 leaf analysis figures are not included.

For practical ferilization advice leafanalysis is an essential supplement to soil analysis. The fall in the phosphate and potassium contents caused by increasing nitrogen fertilization again shows clearly that the plant should be fertilized "harmoniously".

An excessive amount of nitrogen may intensify the potassium deficiency (14, $15,29,51)$ while too little nitrogen may cause severe magnesium deficiency $(3,6,20)$. Nitrogen led to a fall in the $\mathrm{K} / \mathrm{Mg}$ ratio in the leaf, and this also changes the relationship between the $\mathrm{Mg}$ content of the leaf and the $\mathrm{K} / \mathrm{Mg}$ ratio in the soil (20).

Care should be taken to ensure an adequate supply of $\mathbf{K}$ with an abundant nitrogen dressing, one reason being that this imparts a good colour to the fruit (49). 
On the other hand a high phosphate content on fields cultivated in practice shows that too little nitrogen has been supplied to the crop $(26,45)$.

\section{REFERENCES}

1 - - : La fumure du pommier en vergers intensifs (Saint Cobain, 16. Av. Matignon Paris 8e) pp. 56.

2 Beattie, J. M.: Carbohydrates in apple shoots and twigs and their relation to nitrogen fertilization, yield, growth and fruit color. Proc. Am. Soc. Hort. Sci. 51 (1948) $33-40$.

3 - - : Nitrogen fertilization of apples. Ohio Agr. Exp. St. Res. Bull. 817 (1958) pp. 22.

4 Boon, J. van DER : Appel : Jonathan op M XVI in de R.T.C. Geldermalsen en Kesteren. Rapport R.T.C. Bodemaangelegenheden (1957) pp. 25.

5 Bos, J.: Hoeveel voedingsstoffen neemt een boomgaard uit de bodem op ? Meded. Dir. Tuinbouw (1943) 36-43.

6 Boynton, D. a.o. : Responses of Mc Intosh apple orchards to varying nitrogen fertilization and weather. Cornell. Un. Agr. Exp. St. memoir. 290 (1950).

7 - -, L. C. Anderson: Some effect of mulching, nitrogen fertilization and liming on Mc Intosh apple trees and the soil under them. Proc. Amer. Soc. Hort. Sci. 67 (1956) 26-36.

8 ButıN, J.: Stikstofvoeding van fruitgewassen in de volle grond. Meded. Dir. Tuinbouw 19 (1956) 696-705.

9 - - and J. vAN DER BOoN: Correcties in opbrengsten van vruchtbomen in verband met de boomgrootte. Meded. Dir. Tuinbouw 20 (1957) 42-45.

10 CAIN, J. C. : The effect of nitrogen and potassium fertilization on the performance and mineral composition of apple-trees. Proc. Amer. Soc. Hort. Sci. 62 (1953) 46-52.

11 - - : The adsorption and distribution of mineral nutrients in apple trees as effected by nutrient supply. Proc. Amer. Soc. Hort. Sci. 62 (1953) 53-66.

12 - - and D. Boynton: Some effects of season, fruit crops and nitrogen fertilization on the mineral composition of Mc Intosh leaves. Proc. Amer. Soc. Hort. Sci. 51 (1948) 13-22.

13 Childers, N. F. : Mineral nutrition of fruit crops. (Somerset, New Yersey, 1954) pp. 906.

14 Cullican, F. P. and L. P. Batjer : Nitrogen, phosphorus and potash interrelationships in young apple and peach trees. Soil Sci. 55 (1943) 49-60.

15 Dam, J. C. C. vav: Resultaten van het N-P-K-proefveld op het fruitteeltproefbedrijf te Numansdorp. Fruitteelt 48 (1958) 1162-1164.

16 Drosdofr, M., a.o.: Interrelations of source of nitrogen with levels of nitrogen, calcium and magnesium in tung nutrition. Proc. Amer. Soc. Hort. Sci. 65 (1955) $32-40$.

17 Dijкshoors, W. : Nitrogen, chlorine and potassium in perennial ryegrass and their relation to the mineral balance. Neth. J. Agr. Sci. 6 (1958) 131-138.

18 - - : Nitrate accumulation, nitrogen balance and cation-anion ratio during the regrowth of perennial ryegrass. Neth. J. Agr. Sci. 6 (1958) 211-221.

19 Goodall, D. W. and F. G. Gregory : Chemical composition of plants as an index of their nutritional status. Imp. Bur. Hort. Pl. Crops, Techn. Comm. 17 (1947).

20 Gruppe, W. : Vergleichende Blatt- und Bodenuntersuchungen in Apfelplantagen und Baumschulen unter besonderer Berücksichtigung von Kalium und Magnesium. Gartenbauwissenschaft 20 (1955) 419-439.

21 Helmy, A. K., M. M. Elgabaly : Exchange capacity of plant roots, II. Some factors affecting the cation exchange capacity. Plant and Soil 9 (1958) 1-7.

22 Hill, H. : Foliage analysis as a means of determining orchard fertilizer requirements. Int. Hort. Congress, London (1952) Sect. I.

23 Huffaker, R. C. and A. Wallace: Variation in root cation exchange capacity within plant species. Agron. J. 51 (1959) 120.

24 Kobes, F. : Die Versorgung der Obstbäume mit Mineralstoffen. Gartenbauwissenschaft 23 (1958) 43-53.

25 Lagasse, F. S., a.o. : The effects of two levels of nitrogen, phosphorus, potassium and calcium in factorial combination on tung oil production. Proc. Amer. Soc. Hort. Sci. 67 (1956) 165-170. 
26 Lilleland, O.: Personal communication.

27 Mason, A. C. : A note on differences in mineral content of apple leaves associated with fruiting. East M. Res. Sta. Annual Report, 1954.

28 Mc Lean, E. O., a.o. : Cation exchange capacities of plant roots as related to their nitrogen contents. Soil Sci. Soc. Am. Proc. 20 (1956) 345-348.

29 Merrill., S. and G. F. Potter : Effects of nitrogen, phosphorus and potassium on mature tung trees growing on Red Bay fine sandy loam. Proc. Amer. Soc. Hort. Sci. 65 (1955) 41-48.

30 Mulder, E. G. : Stikstofbemesting en magnesiumvoeding van landbouwgewassen. Stikstof 11 (1956) 337-355.

31 Olsen, R. A. and A. F. Dreier: Nitrogen, a key factor in fertilizer phosphorus efficiency. Soil Sci. Soc. Am. Proc. 20 (1956) 509-514.

32 PAAUW, F. van DER : Grote kalibehoefte in droge en geringe in regenrijke jaren. Landbouwvoorlichting 14 (1957) 520-524.

33 - - : Anpassung der Düngung an die Witterungsverhältnisse. Verhandl. II u. IV, Kommission Internat. Bodenk. Gesellsch. Hamburg 2 (1958) 78-82.

34 Pfaff, C. und A. Buchner: Die Abhängigkeit der Magnesiumwirkung vom Kalkzustand und von der Form der Stickstoffernährung. Z. Pflanz. Ern. Düng. Bod. 81 (1958) $102-117$.

35 - - und H. WILl: Düngungsversuche mit Apfelbäumchen in Gefässen. Gartenbauwissenschaft 23 (1958) 182-199.

36 Pouwer, A. : De invloed van de regenval op de kali-opname van vruchtbomen. Meded. Dir. Tuinbouw 19 (1956) 291-297.

37 Ritter, C. M. : Effect of varying rates of nitrogen fertilization on young Elberta peach trees. Proc. Amer. Soc. Hort. Sci. 68 (1956) 48-55.

38 Scharrer, K. und J. Jung : Der Einfluss der Ernährung auf das Verhältnis von Kationen zu Anionen in der Pflanze. Z. Pflanz. Düng. Bod. 71 (1955) 76-93.

$39--,-\ldots$ : Weitere Untersuchungen über die Nährstoffaufnahme und das Verhältnis von Kationen zu Anionen in der Pflanze. Z. Pflanz. Düng. Bod. 71 (1955) 97-113.

40 SмIтн, P. F., a.o. : Effect of differential nitrogen, potassium and magnesium supply to young valencio orange trees in sand culture on mineral composition especially of leaves and fibrous roots. Plant Physiol. 29 (1951) 349-355.

40 SMith, R. L. and A. Wallace : Influence of nitrogen fertilization, cation concentration and root cation exchange capacity on calcium and potassium uptake by plants. Soil Sci. 82 (1956) 165-172.

42 SPREnGer, A. M. and J. H. ter KUILE: Jaarverslag over 1953 van het Centrale bemestingsproefveld De Lange Ossekampen.

43 Steenbjeng, F. : Yield curves and chemical plant analysis. Plant and Soil 3 (1951) $97-109$.

44 - - : Manuring, plant production and the chemical composition of the plant. Plant and Soil 5 (1954) 226-242.

45 Surama, T. and H. Mori: Studies on leaf analysis of apple trees. 3. The relation of leaf $\mathrm{N}, \mathrm{P}$ and $\mathrm{K}$ to fruit colour in apples. Bull. Tohoku Nat. Agr. Exp. St., 1958, no. 13 (Ref. Hort. Abstr. 29 (2) 1959, 223).

46 Thоmpson, A. H., a.o. : A leaf analysis survey of apple orchards in West. Virginia. West Virg. Un. Agr. Exp. St. Bull. 356 (1952).

47 Wallace, A. and R. T. Ashcroft : Preliminary comparisons of the effects of urea and other nitrogen sources on the mineral composition of rough lemon and bean plants. Proc. Amer. Soc. Hort. Sci. 68 (1956) 227-233.

48 W ANDER, I. W. and J. W. Sites : The effects of ammonium and nitrate nitrogen with and without $\mathrm{pH}$-control on the growth of rough lemon seedling. Proc. Amer. Soc. Hort. Sci. 68 (1956) 211-226.

49 WeEks, W. D., a.o. : The effect of rates and sources of nitrogen, phosphorus and potassium on the mineral composition of Mc Intosh foliage and fruit color. Proc. Amer. Soc. Hort. Sci. 60 (1952) 11-21.

$50--$ : The effect of varying rates of nitrogen and potassium on the mineral composition of Mc Intosh foliage and fruit color. Proc. Amer. Soc. Hort. Sci. 71 (1958) $11-19$.

51 Weissenbonk, K. : Die Bemessung der Stickstoffgaben im Obstbau mit Hilfe der Blattanalyse. Landw. Forsch., Sonderheft 9 (1957) 60-67. 